Jef Verschueren, Jan-Ola Östman,

Jan Blommaert \& Chris Bulcaen (eds.)

Handbook of Pragmatics 1997

(C) 1997. Amsterdam/Philadelphia: John Benjamins Publ. Co

\title{
Bronislaw Kasper MALINOWSKI
}

\author{
Gunter Senft
}

\section{Biographical sketch}

“...he had an artist's power to create with great integrative capacity a world of his own ... and he had the true scientist's intuitive discrimination between relevant and adventitious fundamental and secondary issues", this kind epitaph, which Malinowski formulated in his obituary for Sir James George Frazer a year before he himself died, could equally apply to Malinowski, as Raymond Firth (1981: 137) so rightly emphasized in one of his articles on his teacher and colleague. Bronislaw Malinowski, one of the most important anthropologists of the 20th century, is generally recognized as one of the founders of social anthropology, transforming 19th century speculative anthropology into a field-oriented science that is based on empirical research. Malinowski is principally associated with his field research of the Mailu and especially of the Trobriand Islanders in what is now Papua New Guinea, and his masterpieces on Trobriand ethnography continue "to enthrall each generation of anthropologists through its intensity, rich detail, and penetrating revelations" (Weiner 1987: xiv).

Bronislaw Kasper Malinowski (nicknamed Bronek and Bronio) was born in Cracow (then Austrian Galicia, now Poland) on 7 April 1884 as the only child of Jozefa (née Lacka) and Lucjan Malinowski. His father (1839-1898) was professor of Slavonic philology at the Jagiellonian University of Cracow and was well known not only as a philologist but also as an ethnographer specialized in Polish dialects and Silesian folklore and ethnology. He died of a heart attack at the age of 58 when his son (who was to die in the same way at the same age) was only 14 . However, his mother Jozefa ('Josephine', 1848-1918), who came from a wealthy land-owning family and 
projected field site. It was R. L. Bellamy, the Assistant Resident Magistrate and Medical Officer of the district, who attracted Malinowski to the Trobriands. On his arrival on the Trobriands in July, Malinowski stayed with Bellamy, who taught him some basics of Kilivila (also: Kiriwina, Boyowa), the Austronesian language of the islanders (Senft 1986). Bellamy left the Trobriands after a month for the War, but Malinowski decided to stay there and he chose Omarakana, the village of the paramount chief To'uluwa, as the place to set up his tent. Already in September 1915 he mastered the language so well that he did not need the help of an interpreter any more (besides his mother tongue Polish he could also speak Russian, German, French, English, Italian, and Spanish). Malinowski stayed on Kiriwina, the largest of the Trobriand Islands, for nine months, then returned to Melbourne at the end of March 1916 (see Young 1984: 20) and started to write his article Baloma - the Spirits of the Dead in the Trobriand Islands (Malinowski 1974: 149-254). He managed to get a permit to continue his research on the Trobriands for another year, but he was not allowed to go anywhere else and thus had to give up his plans to briefly visit Rossel Island after his second field trip to the Trobriands. Seligman in England and Spencer in Australia managed to raise further funds for his research (from 1914 to 1920 Malinowski had a budget of 250 pounds a year), and Malinowski left Australia again in October 1917 for the Trobriands where he stayed until October 1918 (see Young 1984). It was during the second period of field research on the Trobriands, in January 1918, that Malinowski's mother died.

Back in Melbourne he continued working on his Trobriand material together with Elsie Rosaline Masson. Malinowski had met Elsie in 1916, and they married in March 1919. They had three daughters, Josefa Maria, Wanda, and Helen. A year after their marriage the couple left Australia for good. They first spent some months in England, then they moved to the Canary Islands and lived for a year in a country villa in Tenerife. Here Malinowski finished his first monograph on the Trobriand Islands, The Argonauts of the Western Pacific, which was accepted by Routledge within three days and published in 1922. This book made Malinowski's reputation. In 1921 Malinowski started to give lectures at the LSE. In 1924 he was appointed to a readership in anthropology, and in 1927 he accepted the offer to become the first chair in anthropology at the LSE. Between 1921 and 1927 the Malinowski family travelled to the south of France, to Poland and to the south of Tyrol — where in 1923 they bought a beautiful Alpine house in Oberbozen (Soprabolzano) that was to become the home of the family for 6 years. During this time Malinowski continuously 
commuted between London and Oberbozen.

He was a brilliant teacher, attracted students from many disciplines and trained a generation of distinguished British anthropologists. Among his students were Raymond Firth, E.-E. Evans Pritchard, Isaac Schapera, Hortense Powdermaker, Edmund R. Leach, Meyer Fortes, Lucy Mair, and Ian Hogbin (see also Firth 1957b). The Director of the LSE, Sir William Beveridge, urged Malinowski to live in London — and in 1929 the family moved to a house in Primrose Hill. Moreover, following the advice of Beveridge, Malinowski also became a British subject. He remained in London for almost twenty years, but he continued to travel widely. In 1926 Malinowski was invited to the United States and spent 6 months there as a guest of the Rockefeller Foundation. He visited Ruth Benedict at Columbia and gave a summer course on anthropology at the University of Califormia, Berkeley. He also visited the Hopi Indians and travelled to Mexico for the first time.

The years between 1923 and 1938 were his most productive years as a writer and a teacher. Besides many essays and shorter theoretical works Malinowski published the other two of his three major monographs on the Trobriands, The Sexual Life of Savages in Northwestern Melanesia in 1929 and the two volumes of Coral Gardens and their Magic in 1935. Among his shorter essays on aspects of Trobriand ethnography Magic, Science and Religion (1925), Crime and Custom in Primitive Society (1926), and Myth in Primitive Psychology (1926) deserve special mention. With respect to his interdisciplinary research in anthropology and psychology his publications titled The Psychology of Sex (1923), Psychoanalysis and Anthropology (1924), and The Father in Primitive Psychology (1927) have to be mentioned as well. In her article on Malinowski, Rhoda Métraux (1968) lists 70 publications (see also Ellen et al, 1988: 210-227; Firth 1957b: 265-271).

In 1930 Malinowski developed an interest in Africa. He travelled for four months through South and East Africa, visiting his students (Audrey Richards, the Wilsons, and Hilda Beemer) who were working on the Bemba, the Swazi and on other tribes. Among his African students was Jomo Kenyatta, who prepared his book Facing Mount Kenya (published with an introduction by Malinowski) as a diploma thesis under his supervision.

In 1933 Malinowski made his second visit to the USA, presenting the Messenger lectures at Cornell University. Two years later, in September 1935, his wife Elsie died. In 1936 Malinowski was awarded the honorary doctor of science degree from Harvard University, and in 1938 he spent his sabbatical leave in the 
USA. In September 1939 the director of the LSE, Sir A. M. Carr-Saunders, advised Malinowski to stay in the States because of the unclear wartime future of his university. Malinowski followed this advice and brought his daughters to America. In the same year he became a Bishop Museum Visiting Professor of Anthropology at Yale (where the brilliant teacher had difficulties with students who - according to Métraux (1968: 546) — "were far less mature than his students in London"). In 1939 he also married Valetta Swann (née Hayman-Joyce), an English painter 20 years his junior. Together with his second wife and the Mexican anthropologist Julio de la Fuente he spent the summers of 1940 and 1941 in Mexico doing fieldwork studying the Zapotec Indians' peasant market in Oaxaca. Early in 1942 Malinowski was appointed professor of anthropology at Yale, but on the 16th of May 1942 he suffered a heart attack and died in New Haven, Connecticut.

\section{The study of culture}

As Métraux (1968:54I) pointed out so pertinently, "Malinowski's primary scientific interest was in the study of culture as a universal phenomenon and in the development of a methodological framework that would permit the systematic study of specific cultures in all their peculiarities and open the way to systematic cross-cultural comparison". Central and recurrent themes in his research were the following topics: the family, kinship, culture change, anthropology and psychology, the integrity of culture; the complex interrelationship of the society, the culture and the individual, and the systematic nature of culture.

In his 1931 article on "Culture" in the Encyclopedia of the Social Sciences Malinowski states that for him "culture comprises inherited artefacts, goods, technical processes, ideas, habits, and values". Moreover, besides social organization the concept of culture also includes "the set of forces impinging on the individual born into each society" (Richards 1957:21). For Malinowski this idea of the "... 'social heritage' is the key concept of cultural anthropology" (Malinowski 1931: 621). He was convinced that human beings have biological needs that culture satisfies, that culture is an instrumental reality derived from human needs: "....rites, beliefs, and customs, however extraordinary they appear to an observer, actually fill 'needs', biological, psychological, and social" (Richards 1957: 18). Therefore anthropology is the science that has the task to "study the 'use' or 'function' of the customs, institutions, and 
beliefs which formed part of each culture" (Richards 1957: 16). Each culture represents for him a closed system, and therefore all cultures are comparable.

On the basis of these ideas he developed his functional theory of needs "in which each basic human biological need triggers a cultural response" (Weiner 1987: $\mathrm{xxx}$ ). Functionalism "aims at the explanation of anthropological facts at all levels of development by their function, by the part which they play within the integral system of culture, by the manner in which they are related to each other within the system, and by the manner in which this system is related to the physical surroundings. It aims at an understanding of the nature of culture, rather than at conjectural reconstructions of its evolution or of past historical events...". Moreover, functional theory “... insists... upon the principle that in every type of civilisation, every custom, material object, idea and belief fulfils some vital function, has some task to accomplish, represents an indispensable part within a working whole" (Malinowski 1926: 132, 133). Understanding a culture therefore presupposes the understanding of such functions (for a synthesis of his ideas on functional theory see Malinowski 1944; see also Young 1987: 132ff). However, as Métraux (1968: 541) points out, although "the idea of 'function' is a key concept throughout his work ... his use of the term was openended, exploratory, and subject to continual modification".

His theoretical thinking was very much influenced by Westermarck and Seligman, of course, but also by Wilhelm Wundt, Karl Bücher, James Frazer, Alfred Haddon, William Rivers and R. R. Marrett, by the French sociological school, especially by Emile Durkheim and Marcel Mauss (though he did not like their abstract notions of society), by Richard Thurnwald, by Richard Gregory, Havelock Ellis, A. H. Gardiner, Julian Huxley, C. K. Ogden, Cyril Burt, S. S. Myers, J. C. Flugel, W. Powys Mathers, G. H. L. F. Pitt-Rivers, and J. H. Oldham (see Firth 1957a). He reacted strongly against the speculations of evolutionists and diffusionists like Lewis Henry Morgan, Herbert Spencer, Edward Burnett Taylor, Fritz Graebner, Wilhelm Schmidt and other representatives of the Kulturhistorische Schule and their Kulturkreislehre, against Lévy-Bruhl's theory of primitive mentality, and against Freud's theory of psychoanalysis.

On the basis of his theoretical ideas about culture he studied a broad range of cultural aspects and institutions - mainly, if not almost exclusively, with respect to the culture of the Trobriand Islanders - and he challenged in, and with, his work many theories on core-concepts of anthropology such as kinship, marriage, exchange, and ritual. 
For Malinowski, functionalism was a research tool, "the prerequisite for fieldwork and for the comparative analysis of phenomena in various cultures" (Malinowski 1944: 175), and therefore his theory had to include a general theory of how to do fieldwork.

\section{Fieldwork}

Malinowski was not the first anthropologist who did intensive field research - Lewis H. Morgan studied the Iroquois, Franz Boas the Kwakiutl, Carl Strehlow as well as Spencer and Gillen Australian Aborigines in the field - but through "his example and teaching, fieldwork became the 'constitutive experience' of anthropology, the 'central rite of the tribe" (Young 1987: 124). As Leach (1957: 120) points out so aptly, Malinowski, the 'fanatical theoretical empiricist', developed a field technique that was unique because of the "severely curtailed use of the professional informant" and because of "the theoretical assumption that the total field of data under the observation of the field worker must somehow fit together and make sense". He was convinced that observation without theory is impossible. However, he also insisted on the principle that theory can only be falsified or verified on the basis of the observed and that the observed will always lead to a refinement or to a reformulation of basic assumptions in the field researcher's theory. Already in his 1916 article Baloma - the Spirits of the Dead in the Trobriand Islands Malinowski (1974: 237f.) emphasized that the traditional gathering of 'pure facts' in the field is 'pure 'collectioneering' of data' if it is not accompanied by "the interpretation which sees in the endless diversity of facts general laws; which severs the essential from the irrelevant; which classifies and orders phenomena, and puts them into mutual relationship". Thus, "field work consists only and exclusively in the interpretation of the chaotic social reality, in subordinating it to general rules". In his introduction to the Argonauts of the Western Pacific he clearly formulates the basic lines of his approach to field research and the final goal of an ethnographer:

...the goal of ethnographic fieldwork must be approached through three avenues:

1. The organisation of the tribe, and the anatomy of its culture must be recorded in firm clear outline. The method of concrete statistical 
documentation is the means through which such an outline has to be given.

2. Within this frame, the imponderabilia of actual life, and the type of behoviour have to be filled in. They have to be collected through minute, detailed observations, in the form of some sort of ethnographic diary, made possible by close contact with native life.

3. A collection of ethnographic statements, characteristic narratives, typical utterances, items of folklore and magical formulae has to be given as a corpus inscriptionum, as documents of native mentality.

These three lines of approach lead to the final goal, of which an Ethnographer should never lose sight. This goal is, briefly, to grasp the native's point of view, his relation to life, to realise his vision of his world. We have to study man, and we must study what concerns him most intimately, that is, the hold which life has on him.... In each culture we find different institutions... To study the institutions, customs, and codes or to study the behaviour and mentality without the subjective desire of feeling by what these people live, of realising the substance of their happiness - is, in my opinion, to miss the greatest reward which we can hope to obtain from the study of man.... Perhaps as we read the account of these remote customs there may emerge a feeling of solidarity with the endeavours and ambitions of these natives. Perhaps man's mentality will be revealed to us, and brought near, along some lines which we never have followed before. Perhaps through realising human nature in a shape very distant and foreign to us, we shall have some light shed on our own. (Malinowski 1922: 24f.)

Thus, Malinowski introduced the concept and the method of "participant observation" into anthropology, being convinced that "alien cultures had to be explored "from the inside' to make most sense" (Young 1987: 131). That this ambitious concept necessarily puts field researchers in a position where they have to face the strains of field research is very explicitly and incredibly frankly documented in Malinowski's posthumously published Diary (Malinowski 1967), which Raymond Firth in his new introduction to the 1989 edition (re-)evaluates as follows: "It is not merely a record of the thinking and feeling of a brilliant, turbulent personality .... it is also a highly significant contribution to the understanding of the position and role of a fieldworker as a conscious participator in a dynamic social situation" (Firth 1989: xxxi). 
words belong" (Malinowski 1935: 58). Malinowski emphasizes that language - at least in its primitive function - has to be regarded as a mode of action (Malinowski 1923: 296; see also Firth 1957: 94); and that to understand the use of a complex speech situation requires the understanding of the situation in which it occurred and the action it accomplished. This position can certainly be described as a "radical functionalism and contextualism" (Nerlich \& Clarke 1996: 323). Malinowski (1923: 296, 309ff) illustrates how the meaning of utterances can be determined in what he calls "the essential primitive uses of speech: speech in action, ritual handling of words, the narrative, "phatic communion' (speech in social intercourse)"; he emphasizes his main position as follows: "language in its primitive function and original form has an essentially pragmatic character; ... it is a mode of behaviour, an indispensable element of concerted human action ... to regard it as a means for the embodiment or expression of thought is to take a one-sided view of one of its most derivate and specialized functions" (Malinowski 1923: 316 ; see also Firth 1957: 94; Langendoen 1968: $21 \mathrm{ff}$ ). Moreover, Malinowski is convinced that language "serves for definite purposes, that it functions as an instrument used for and adapted to a definite aim". Malinowski exemplifies the essentially pragmatic character of language by referring to two situations from his Trobriand experience - a fishing expedition (Malinowski 1923: 310-312) and the verbal guiding of a boat into a reef channel in complete darkness (Malinowski 1935: 58f.) — in which he noted that "words have to be uttered with impeccable correctness and understood in absolutely adequate manner in ... situations where speech is an indispensable adjunct to action" (Malinowski: 1935: 58). Malinowski sums up his analysis of the linguistic actions he observed during the fishing expedition as follows:

All the language used during such a pursuit is full of technical terms, short references to surroundings, rapid indications of change - - all based on customary types of behaviour, well-known to the participants from personal experience. Each utterance is essentially bound up with the context of situation and with the aim of the pursuit, whether it be the short indications about the movements of the quarry, or references to statements about the surroundings, or the expression of feeling and passion inexorably bound up with behaviour, or words of command, or correlation of action. The structure of all this linguistic material is inextricably mixed up with, and dependent upon, the course of the 
activity in which the utterances are embedded. The vocabulary, the meaning of the particular words used in their characteristic technicality is no less subordinate to action. For technical language, in matters of practical pursuit, acquires its meaning only through personal participation in this type of pursuit. It has to be learned, not through reflection but through action. ... The study of any form of speech in connection with vital work would reveal the same grammatical and lexical peculiarities: the dependence of the meaning of each word upon practical experience, and of the structure of each utterance upon the momentary situation in which it is spoken. Thus the consideration of linguistic uses associated with any practical pursuit, leads us to the conclusion that language in its primitive forms ought to be regarded and studied against the background of human activities and as a mode of behaviour in practical matters. Malinowski (1923: $311 \mathrm{f}$.)

It is obvious that Malinowski here emphasizes and stresses "action at the expense of structure and system" (Nerlich \& Clarke 1996: 333). He even argues further that this "adaptation, this correlation between language and the uses to which it is put, has left its traces in linguistic structure" (Malinowski 1923: 327). Therefore, for Malinowski "the categories of universal grammar are reflections of universal human attitudes toward life and are brought out by the universally found conditions under which children grow up in the world" (Langendoen 1968: 27). Thus, these "categories of universal grammar must underlie categorizations implicit in nonlinguistic human behavior" (Langendoen 1968: 36). In the second volume of Coral gardens and their magic Malinowski developed the central idea of his theory, namely "that the meaning of utterances is provided by the context of concurrent human activity" (Langendoen 1968: 30). He once more points out that "the real linguistic fact is the full utterance within its context of situation" (Malinowski 1935: 11). And he emphasizes "that the context of situation may enable one to 'disambiguate' sentences that are semantically ambiguous" (Langendoen 1968: 32; see Malinowski 1935: 32).

Langendoen presents a rather fair and competent criticism of Malinowski's linguistic views. However, he seems to underestimate the importance of what J. R. Firth (1957: 118) referred to as Malinowski's “outstanding contribution to linguistics", namely "his approach in terms of his general theory of speech functions in contexts of situation, to the problem of meaning in exotic languages and even in our own". Malinowski certainly had a major impact on English linguistics in the first half of our 
century. And within linguistics, anthropology and anthropological linguistics some of Malinowski's ideas about language continue to be thought-provoking, and - with explicit reference to Malinowski - social scientists have started 'rethinking context' (Duranti \& Goodwin 1992).

\section{An appraisal}

Malinowski's work and his theory of language and culture has been amply criticized and discussed (Firth 1957b, Weiner 1987, Kohl 1987, Agar 1994, Nerlich, Clarke 1996: 317-335). In what follows I will give an assessment and appraisal of the master of Trobriand ethnography on the basis of my own field research on the Trobriand Islands.

I cannot but completely agree with Michael Young (1987: 138) that Malinowski "was an incomparable fieldworker and master ethnographer". The only reliable linguistic data I found in the literature preparing for my first 17 months of field research on the Trobriands in 1982/83 came from Malinowski's linguistic publications and from his anthropological linguistic remarks in his ethnographic masterpieces on the Trobriand Islanders. Bits and pieces of Kilivila linguistics that I found in Capell, Lithgow, and Greenberg turned out to be either utterly wrong or extremely speculative (see Senft 1991: 27, 46). Moreover, I had the quite romantic feeling when I first set foot on the Trobriands in 1982 that it was like stepping right into the picture so vividly presented in Malinowski's Trobriand ethnography (Senft 1992: 68). I could easily verify major aspects of his exceptionally thorough ethnographic description of Trobriand culture in my own experience as a participant observer.

Although the Trobriand culture - as well as the Kilivila language, of course have been affected by numerous changes since Malinowski worked and lived there (see Senft 1992, 1997a, b), I have always found it worth my while to check my observations and insights with Malinowski's publications. There are two excellent ethnographic restudies on the Trobriands. First of all Harry A. Powell's An Analysis of Present Day Social Structure in the Trobriand Islands, his 1957 Ph.D-thesis, "is envisaged as supplementary to Malinowski's published data" and presents "a theoretical interpretation of Trobriand kinship and marriage relations different from that developed by Malinowski" (Powell 1957: Abstract of thesis). Second, the results from the 1978 "Kula and Massim Exchange Conference" in Cambridge published by 
Leach \& Leach (1983) present an excellent reassessment of Malinowski's classic study of 1922. One of the few ethnographic niches Malinowski left, the 'female world' on the Trobriands, was congenially filled by Annette Weiner $(1976,1988)$. It is extremely difficult to find other such niches (see e.g. Senft \& Senft 1986, Senft 1994b: 65f) with respect to Trobriand ethnography (but not, of course, with respect to linguistic research on Kilivila). Moreover, I found it equally difficult to falsify major aspects of his ethnography. However, there is one - hotly debated - topic in Malinowski's description of Trobriand sexuality where I am convinced that Malinowski either made a gross mistake or played 'career politics' (or even took his peer group for a ride?) - I am referring to the controversy over Trobriand "virgin birth".

In 1983 my wife stayed with me for 11 months on the Trobriands. We then had no children, and after my wife had learnt to speak Kilivila, the women started to discuss contraception with her. The women of Tauwema told my wife that they had two means of contraception that are both based on a mixture of herbs that grow in the bush; to this mixture a little bit of water is added. Some women but also some men know how to prepare this fluid based on the herbal composition. Once the women had talked about this topic, I could easily verify this information with two of my male informants, namely with Weyei, the weather-magician of Tauwema (see Senft 1985a, 1997b), and Vapalaguyau, who both were very proud of the expertise which they had inherited from their ancestors; however, they did not want to show me how and with which herbs they produce this mixture (I respected their reservations and did not urge them for further information about something that is as personal and secret as magic). Anyhow, there are two modes of application for this contraceptive. Either, before the coitus the woman drips the fluid on a small sponge and then inserts it into her vagina placing it in front of her os uteri - the herbal composition is spermatocidal and thus prevents contraception. Or, the woman drinks the herbal composition in a more hydrous solution. The problem with this second mode of application is that the ratio between the herbal mixture and the water is rather delicate: the contraceptive effect of the drink may either last for a few days only or for years - and if the herbal mixture is too highly concentrated it may even cause sterility. Such a long term effect of the contraceptive almost endangered the marriage of a loving couple - however, when we returned to the Trobriands in 1989 (with our then 2 and 4 year old children), the woman who six years ago poured out her troubles to me and especially to my wife proudly presented us her two children. (l would like to note here that the "yam or Dioscorea" - the most important part of the Trobriand diet - "was long known by 
certain Mexican Indians to have a contraceptive effect. In 1993 Dr. Russell Marker ... determined the molecular structure of diosgenin, a stereoid substance with progesteronic effect derived from the yam root. Based on this information, Organon, a leading producer of contraceptive pills, uses the diosgenin from Mexican yam roots as the raw material for some of its products" (de Revai: 1992) - but this is just an aside). The fact that the Trobriand Islanders know about natural contraceptives and that this knowledge is traditional is - to my mind - a clear and convincing counterargument against Malinowski's claim which he first made in his very first publication on the Trobriands in 1916, Baloma; the Spirits of the Dead in the Trobriand Islands (Malinowski 1974: 220-237), which he used like a beat of a drum to introduce his "sex book" (as he himself and his first wife called it, see Weiner 1987: xxxii), and which he elaborates in chapter 7 of The Sexual life of Savages in North-Western Melanesia, namely that the Trobriand Islanders are ignorant of the role of the 'pater' as 'genitor'.

Given Malinowski's excellent command of Kilivila and the incredible amount of magical formulae he managed to collect and to translate - texts that represent secret and inherited knowledge which was up till 1983 well guarded by the experts and almost exclusively bestowed on relatives (i.e. within the matrilineal line, see Senft 1997b) - it is very hard for me to understand why the master of Trobriand ethnography did not hit upon the fact of Trobriand natural contraceptives, but took the Trobriand "myth" of conception and "virgin birth" not as a kind of ideology with the function (!) to diminish discrimination of extramarital births and to allow obviously cuckolded men to keep their face (see Weiner 1976: 122, Sprenger: 1997: 61 ff). Note also that the incident Weiner reports about a man who returns after his year-long absence to his village and to his wife and who reacts extremely jealous when his wife presents him with a new born child, is just another confirmation of the fact that this man obviously knew about physical paternity.

I can only explain this - for me rather open and blunt - mistake of Malinowski's in two ways. Either he became the victim of the Trobriand Islanders' love of making fun of people - with their metalinguistic vocabulary they also differentiate the so-called 'Biga Sopa', the lying or joking or indirect language (see Senft 1985b, 1986: 125) — and they really took him for a ride, or - but this alternative is a somewhat nasty imputation - he used this "exotic" claim to promote his academic career even further. In her introduction to the latest edition of The Sexual Life of Savages Weiner (1987: xxvii) discusses Malinowski's relation to psychoanalysis in detail and refers to Stocking (1986) with a footnote, in which she states: "According 
to Stocking (pp. 32-33) Malinowski's response to psychoanalysis may have been more than intellectual. Rivers, the most eminent figure in British anthropology, died suddenly in 1922, leaving a vacuum in leadership. Stocking suggests that because Rivers had a long interest in psychoanalysis, Malinowski in taking up psychoanalytic debates, strengthened his bid against the diffusionists William Perry and Elliot Smith, to become Rivers's successor" (Weiner 1987: xlii, fn. 19) — and the claim in 'the sex book' could then be interpreted as the final culmination of such a strategic move within academic politics (however, I want to emphasize that this assumption is nothing but a nasty imputation. An even nastier imputation would be to accuse Malinowski of having taken his peer group for a ride with this 'exotic fact' - I still find it extremely interesting and sometimes quite hilarious to note that - with the exception of Anna Weiner - all people engaged in this debate have never set foot on the Trobriand Islands).

However, this obvious mistake does not and cannot diminish Malinowski's incredible achievements within his Trobriand ethnography. With respect to the style in which he presents his insights and analyses of Trobriand culture I have to agree with Robert Redfield (1974: 9) who pointed out that no "writer of our times has done more than Bronislaw Malinowski to bring together in single comprehension the warm reality of human living and the cool abstractions of science. His pages have become an almost indispensable link between the knowing of exotic and remote people as we know our own neighbors and brothers, and conceptual and theoretical knowledge about mankind". According to Mrs. Seligman, Malinowski once said proudly "Rivers is the Rider Haggard of anthropology; I shall be the Conrad" (Firth 1957: 44), and I must confess that I read the books of the Polish ethnographer with the same suspense as the books of his fellow Polish novelist.

With respect to an overall assessment of Malinowski l would like to point out once more that he is one of the most important anthropologists of our century, that he is one of the founders of social anthropology who introduced the concept of "participant observation" into anthropology and who insisted on the ethnographer's linguistic competence in, and competent use of, the language spoken in the culture studied as another absolutely necessary prerequisite for doing sound anthropological research. It is extremely difficult to do justice to such a "protean character" (Firth 1989: xxi) like Bronislaw Kasper Malinowski in a rather short handbook article - the expected publication of Michael Young's biography on this great anthropologist and ethnographer will be more than welcome. 


\section{References}

M. AGAR (1994) Language Shock - Understanding the Culture of Conversation. William Morrow and Co. R. BAUMANN (1992) Text and discourse in anthropological linguistics. In W. Bright (ed.) International encyclopedia of linguistics: 145-147. Oxford Univ. Press. A. DURANTI \& C. GOODWIN (eds.) (1992) Rethinking Context. Cambridge Univ. Press. R. ELLEN, E. GELLNER, G. KUBICA \& J. MUCHA (eds.) (1988) Malinowski between two worlds. The Polish roots of an anthropological tradition. Cambridge Univ. Press. J. R. FIRTH (1957) Ethnographic Analysis and Language with Reference to Malinowski's Views. In R. Firth (ed.): 93-118. - (1957a) Introduction: Malinowski as Scientist and Man. In. R. Firth (ed.): 1-14. (198I) Bronislaw Malinowski. In S. Silverman (ed.) Totems and teachers. Perspectives on the history of anthropology: 101-140. Columbia Univ. Press. - (1989 [1967]) Second Introduction 1988. In B. Malinowski A Diary in the Strict Sense of the Term. xxi-xxxi. The Athlone Press. R. FIRTH (ed.) (1957b) Man and Culture - An Evaluation of the Work of Bronislaw Malinowski. Routledge \& Kegan Paul. K.-H. KOHL (1987) "Der Verdammte der Inseln" Bronislaw Kaspar (sic) Malinowski (1884-1942)". In K.-H. Kohl Abwehr und Verlangen: zur Geschichte der Ethnologie. 39-62. Edition Qumran im Campus Verlag. D. T. LANGENDOEN (1968) The London School of Linguistics: A Study of the Linguistic Theories of B. Malinowski and J. R Firth. The MIT Press. E. R. LEACH (1957) The Epistemological Background to Malinowski's Empiricism. In. R. Firth (ed.): 119-137. Routledge and Kegan Paul. J. W. LEACH \& E. LEACH (eds.) (1983) The Kula - New Perspectives on Massim Exchange. Cambridge Univ. Press. B. MALINOWSKI (1920) Classificatory particles in the language of Kiriwina. Bulletin of the school of Oriental studies, London institution, Vol. I, part IV: 33-78. _ (1922) Argonauts of the Western Pacific. Routledge and Kegan Paul.__ (1923) The problem of meaning in primitve languages. In C. K. Ogden \& I. A. Richards, The meaning of meaning. Supplement I. 296-336. Kegan Paul. (1926) Anthropology. In Encyclopedia Britannica. 13th ed. Sup. Vol. 1: 131-140. Benton. (1929) The Sexual Life of Savages in Northwestern Melanesia. Routledge \& Kegan Paul. — (1931) Culture. In Encyclopedia of the Social Sciences, Vol 4: 62 1-646. Macmillan._- (1935) Coral gardens and their magic. Allen \& Unwin. _ (1944) A Scientific Theory of C'ulture and other Essays. Univ. of North Carolina Press. - (1967) A Diary in the Strict Sense of the Term. The Athlone Press. (1974) Magic, Science and Religion and Other Essays. Souvenir Press. _ (1988) Malinowski Among the Magi: The Natives of Mailu. Routledge. R. MÉTRAUX (1968) Bronislaw Malinowski. In International Encyclopedia of Social Sciences Vol. 9: 541-549. 
Crowell Collier \& Macmillan. B. NERLICH, \& D.D. CLARKE (1996) Language, Action and Context - The Early History of Pragmatics in Europe and America, 1780 1930. Benjamins. A. K. PALUCH (1981) The Polish Background to Malinowski's Work. Man 16: 276-285. H. A. POWELL (1957) An Analysis of Present Day Social Structure in the Trobriand Islands. Ph.D. thesis, Univ. of London. M. L. DE REVAI, M.D. (1992) Letter to the Editor: Forum Trobriand Islands. National Geographic 182:5, Nov. 1992. A. I. RICHARDS (1957) The Concept of Culture in Malinowski's Work. In R. Firth (ed.): 15-31. Routledge \& Kegan Paul. R. REDFIELD (1974) Introduction. In B. Malinowski: 9-13. Souvenir Press. B. SENFT \& G. SENFT (1986) Ninikula - Fadenspiele auf den Trobriand Inseln, Papua Neuguinea. Baessler Archiv, Beiträge zur Völkerkunde NF 34, 93-235: G. SENFT (1985a) Weyeis Wettermagie - eine ethnolinguistische Untersuchung von fünf wettermagischen Formeln eines Wettermagiers auf den Trobriand Inseln. Zeitschrift für Ethnologie 10 (1): 67-90, (2) erratum. _— (1985b) How to tell - and understand - a 'dirty' joke in Kilivila. Journal of Pragmatics 9: 815-834. _— (1986) Kilivila The Language of the Trobriand Islanders. Mouton de Gruyter. — (1991) Mahnreden auf den Trobriand Inseln - Eine Fallstudie. In D. FLADER (ed.) Verbale Interaktion - Studien zur Empirie und Methodologie der Pragmatik: 27-49. J.B. Metzler. _ (1992) 'As Time goes by...': Changes observed in Trobriand lslanders' culture and language, Milne Bay Province, Papua New Guinea. In T. DUTTON (ed.) Culture change, language change - case studies from Melanesia. 67-89. Pacific Linguistics, Australian National University. _- (1994a) These "Procrustean" Feelings... - Some Of My Problems In Describing Kilivila. Semaian, 11: 86-105. (1994b) Spatial Reference in Kilivila: The Tinkertoy Matching Games - A Case Study. Language and Linguistics in Melanesia 25: 55-93. Classificatory Particles in Kilivila. Oxford Univ. Press. - (1997a) Magic, missionaries and religion. Some observations from the Trobriand Islands. In T. OTTO, A. BORSBOOM (eds.) Cultural dynamics of religious change in Oceania. 4559. KITLV Press. (1997b) Magical Conversation on the Trobriand Islands. Anthropos 92: 369-391. G. SPRENGER (1997) Erotik und Kultur in Melanesien. Eine kritische Analyse von Malinowskis "The Sexual Life of Savages". LITVerlag. G. W. STOCKING Jr. (1986) Anthropology and the science of the irrational: Malinowski's encounter with Freudian psychoanalysis. History of Anthropology 4: 13-49. H. WAYNE (MALINOWSKA) (1985). Bronislaw Malinowski: the influence of various women on his life and works. American Ethnologist 12: 529-540. (ed.) (1995). The Story of a Marriage. The Letters of Bronislow Malinowski and Elsie Masson. Vol. I 1916-20. Vol. II: 1920-35. Routledge. P. WEGENER (1885) Untersuchungen über die Grundfragen des Sprachlebens. Max Niemeyer. A. B. WEINER (1976) Women of Value, Men of Renown. New Perspectives in Trobriand Exchange. Univ. of Texas Press. - (1987). Introduction. In B. 
Malinowski The Sexual Life of Savages in North-Western Melanesia. xii-xlix. Beacon Press. _ (1988) The Trobriand Islanders of Papua New Guinea. Holt, Rinehart \& Winston. M. W. YOUNG (1984) The Intensive Study of a Restricted Area, Or, Why Did Malinowski Go to the Trobriand Islands. Oceania 55: 1-26. (1987) Malinowski and the function of culture. In D. J. Austin-Broos (ed.). Creating culture. Profiles in the study of culture: 124-140. Allen \& Unwin. 